\title{
Genetics of Resistance to Race TTKSK of Puccinia graminis f. sp. tritici in Triticum monococcum
}

\author{
M. N. Rouse and Y. Jin
}

United States Department of Agriculture-Agricultural Research Service Cereal Disease Laboratory, University of Minnesota, St. Paul 55108. Accepted for publication 14 July 2011.

\begin{abstract}
Rouse, M. N., and Jin, Y. 2011. Genetics of resistance to race TTKSK of Puccinia graminis f. sp. tritici in Triticum monococcum. Phytopathology 101:1418-1423.

Race TTKSK (or Ug99) of Puccinia graminis f. sp. tritici possesses virulence to several stem rust resistance genes commonly present in wheat cultivars grown worldwide. New variants detected in the race TTKSK lineage further broadened the virulence spectrum. The identification of sources of genetic resistance to race TTKSK and its relatives is necessary to enable the development and deployment of resistant varieties. Accessions of Triticum monococcum, an A-genome diploid wild and cultivated wheat, have previously been characterized as resistant to stem rust. Three resistance genes were identified and introgressed into

determine the genetic control and allelic relationships of resistance to race TTKSK in T. monococcum accessions identified through evaluations at the seedling stage. Generation $\mathrm{F}_{2}$ progeny of 8 crosses between resistant and susceptible accessions and 13 crosses between resistant accessions of T. monococcum were evaluated with race TTKSK and often with North American races, including races QFCSC, TTTTF, and MCCFC. For a selected population segregating for three genes conferring resistance to race TTKSK, $\mathrm{F}_{2: 3}$ progeny were evaluated with races TTKSK, QFCSC, and TTTTF. In that population, we detected two genes conferring resistance to race TTKSK that are different from $\mathrm{Sr} 21, \mathrm{Sr} 22$, and Sr35. One of the new genes was effective to all races tested. The identification of these genes will facilitate the development of varieties with new resistance to race TTKSK
\end{abstract} hexaploid wheat: $\operatorname{Sr} 21, \operatorname{Sr} 22$, and $S r 35$. The objective of this study was to
Stem rust, caused by the fungus Puccinia graminis f. sp. tritici, is historically one of the most significant wheat diseases. Emphasis in breeding wheat varieties for stem rust resistance and, in some locations, the removal of the alternate host of $P$. graminis $\mathrm{f}$. sp. tritici, common barberry (Berberis vulgaris), were successful in preventing significant epidemics of this disease in the United States since 1955 and worldwide over the past several decades (8).

Emerging $P$. graminis f. sp. tritici race TTKSK, commonly known as Ug99, is virulent on the majority of the world's currently grown wheat cultivars $(1,3-5,15,18)$. Race TTKSK or variant races have spread throughout eastern and southern Africa, Yemen, and Iran (10). Variants of race TTKSK have been detected throughout Africa with additional virulence to stem rust resistance genes $\operatorname{Sr} 24$ and $\operatorname{Sr} 36(5,6,14)$. Virulence to these genes is significant because of their current use in agriculture $(3,13)$.

A number of designated resistance genes have been identified as effective to race TTKSK (4). Many of these resistance genes are derived from alien relatives of wheat and have not been used in breeding because of linkage drag (18). In order to develop and deploy cultivars resistant to TTKSK and its variants, many of the alien translocations carrying Ug99-effective genes need to be manipulated through chromosome engineering to reduce the linkage drag, as done recently with $\operatorname{Sr} 39$ (11). Furthermore, new

\section{Corresponding author: Y. Jin; E-mail address: Yue.Jin@ ars.usda.gov}

Mention of a trademark, vendor, or proprietary product does not constitute a guarantee or warranty of the product by the United States Department of Agriculture and does not imply its approval to the exclusion of other product or vendors that also may be suitable.

\section{doi:10.1094/PHYTO-05-11-0133}

This article is in the public domain and not copyrightable. It may be freely reprinted with customary crediting of the source. The American Phytopathological Society, 2011. sources of resistance need to be identified to ensure genetic diversity of stem rust resistance in wheat.

Three stem rust resistance genes have previously been introgressed from Triticum monococcum, a wheat relative with a diploid A-genome $(2,7,9,20,21)$. One advantage of introgressing traits from $T$. monococcum as opposed to most other wheat relatives is that $T$. aestivum (bread wheat) chromatin readily recombines with introgressed chromatin from $T$. monococcum. This allows traits introgressed from T. monococcum to be backcrossed into wheat germplasm with ease and provides an opportunity to reduce the size of the alien chromatin and to eliminate linkage to unwanted genes. Reduction of T. monococcum alien chromatin has recently been accomplished for an introgressed T. monococcum segment carrying Sr22 (12).

We previously characterized 1,061 T. monococcum accessions for resistance to stem rust, including race TTKSK (16). Preliminary gene postulations based upon infection type (IT) patterns allowed us to identify several accessions that likely possess new resistance to race TTKSK. The objective of this study was to determine the genetic basis and allelic relationships of resistance to race TTKSK in $T$. monococcum accessions.

\section{MATERIALS AND METHODS}

Plant materials. Accessions of T. monococcum used as parents in this study are listed in Table 1 . The 21 crosses made among these accessions are listed in Table 2 . All accessions belonging to T. monococcum subsp. monococcum (cultivated einkorn) were obtained from the United States Department of Agriculture (USDA) National Small Grains Collection, Aberdeen, ID and accession DV92 was obtained from J. Dubcovsky, University of California, Davis. Most of the IT data of these accessions to various $P$. graminis f. sp. tritici races used in this study were obtained from an earlier report (16). Generation $\mathrm{F}_{2}$ progeny of the crosses were screened with selected $P$. graminis f. $\mathrm{sp}$. tritici races 
(Tables 3, 4, and 5). In addition to race TTKSK, the other four races were included in this study because of their ability to differentiate among the previously introgressed stem rust resistance genes from T. monococcum ( $\mathrm{Sr} 21, \mathrm{Sr} 22$, and $\mathrm{Sr} 35)$. The determination of a $P$. graminis $\mathrm{f}$. sp. tritici race used in inoculating a particular population was based on specific $P$. graminis $\mathrm{f}$. sp. tritici avirulence phenotypes that would allow for discrimination among segregating genes. Generation $\mathrm{F}_{2: 3}$ families were evaluated for the population derived from the cross PI 306540/PI
272557. For each $F_{2}$ population screened, $120 \mathrm{~F}_{2}$ seeds, in addition to 6 seeds of each parent, were planted in a tray containing vermiculite (Sun Gro Horticulture, Bellevue, WA). For many populations, additional $F_{2}$ seed were planted in order to increase sample sizes of plants screened. Also, limited seed was available for some populations, resulting in smaller numbers of seed planted. Different $F_{2}$ seed derived from the same $F_{1}$ plants were used for screening with multiple races of $P$. graminis f. $\mathrm{sp}$. tritici. Trays with seedlings were grown in a greenhouse at the

TABLE 1. Triticum monococcum accessions used as parents in crosses and infection types to selected races of Puccinia graminis $\mathrm{f}$. sp. tritici by these accessions ${ }^{\mathrm{x}}$

\begin{tabular}{|c|c|c|c|c|c|c|}
\hline Accession & TRTTF & TTKSK & TTTTF & QFCSC & MCCFC & Postulated genes \\
\hline PI 272557 & $3+$ & 4 & 4 & 4 & 4 & Susceptible parent \\
\hline CI 2433 & $3+$ & $2+$ & $3+$ & 4 & $; 1$ & $\operatorname{Sr} 21$ \\
\hline PI 190945 & 1 & 1 & $2-;$ & $; 1-$ & $; 1$ & $\mathrm{Sr} 22$ \\
\hline PI 428151-1y & $2+$ & $2-$ & 2 & $; 1$ & $; 1$ & $\mathrm{Sr} 22$ \\
\hline PI 272560 & 0 & 0 & $\mathrm{X}$ LIF & 4 & 4 & Sr35 \\
\hline PI $428170^{z}$ & 0 & 0 & X LIF & 4 & $; 1$ & $\operatorname{Sr} 21, \operatorname{Sr} 35$ \\
\hline DV92 & 0 & 0 & X LIF & $3+$ & 1 & $\operatorname{Sr} 21, \operatorname{Sr} 35$ \\
\hline PI 277131-2 & $3+$ & 0 & $3+$ & ;12- & ; & New \\
\hline PI 306540 & $; 13 Z$ & 0 & $; 13 Z$ & $; 1-$ & 0 & New \\
\hline
\end{tabular}

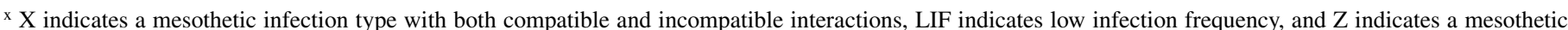
infection type where the higher infection types occur at the leaf base.

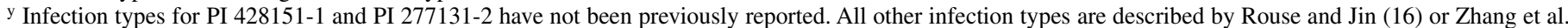
(22).

z Synonymous with G2919.

TABLE 2. Races of Puccinia graminis f. sp. tritici used to screen progeny of Triticum monococcum crosses

\begin{tabular}{|c|c|c|}
\hline Race & Isolate & Virulence/avirulence formula \\
\hline TRTTF & 06YEM34-1 & 5,6,7b,9a,9b,9d,9e,9g,10,11,17,21,30,36,38,McN,Tmp/8a,22,24,31,35 \\
\hline TTKSK $^{\mathrm{z}}$ & 04KEN156/04 & 5,6,7b,8a,9a,9b,9d,9e,9g,10,11,17,21,30,31,38,McN/22,24,35,36, Tmp \\
\hline TTTTF & $01 \mathrm{MN} 84 \mathrm{~A}-1-2$ & 5,6,7b,8a,9a,9b,9d,9e,9g,10,11,17,21,30,36,38,McN,Tmp/22,24,31,35 \\
\hline QFCSC & 03ND76C & 5,8a,9a,9d,9g,10,17,21,35,McN/6,7b,9e,9b,11,22,24,31,30,36,38, Tmp \\
\hline MCCFC & $59 \mathrm{KS} 19$ & 5,7b,9g,10,17,35,McN,Tmp/6,8a,9a,9d,9e,9b,11,21,22,24,31,30,36,38 \\
\hline
\end{tabular}

${ }^{\mathrm{z}}$ Race TTKSK is avirulent to $\mathrm{Sr} 21$ in T. monococcum germplasm. The race name 'TTKSK' is based on reported virulence to $\mathrm{Sr} 21$ in hexaploid lines (4).

TABLE 3. Segregation of resistance in Triticum monococcum $\mathrm{F}_{2}$ progeny involving Sr21, Sr22, or Sr35 to races of Puccinia graminis f. sp. tritici

\begin{tabular}{|c|c|c|c|c|c|c|c|c|c|c|c|}
\hline Cross & Parent 1 & Parent 2 & Race & $\begin{array}{l}\text { Resistant } \\
\text { type } 1^{\mathrm{y}}\end{array}$ & $\begin{array}{c}\text { Resistant } \\
\text { type } 2\end{array}$ & Susceptible & $\begin{array}{l}\text { Expected } \\
\text { ratio }\end{array}$ & $\chi^{2}$ & $P$ & $\begin{array}{c}\text { Segregating } \\
\text { genes }\end{array}$ & $\begin{array}{l}\text { Fixed genes exhibiting } \\
\text { resistance }\end{array}$ \\
\hline $\mathrm{C} 1$ & PI 272557 & CI 2433 & TTKSK & 102 & - & 39 & $3: 1$ & 0.53 & 0.47 & $\operatorname{Sr} 21$ & - \\
\hline $\mathrm{C} 2$ & PI 272557 & PI 428151-1 & TTKSK & 111 & - & 38 & $3: 1$ & 0.02 & 0.89 & $\operatorname{Sr} 21$ & - \\
\hline $\mathrm{C} 2$ & PI 272557 & PI 428151-1 & TTTTF & 50 & - & 19 & $3: 1$ & 0.24 & 0.63 & Sr 22 & - \\
\hline $\mathrm{C} 2$ & PI 272557 & PI 428151-1 & QFCSC & 94 & - & 37 & $3: 1$ & 0.74 & 0.39 & Sr22 & - \\
\hline $\mathrm{C} 3$ & PI 272557 & PI 190945 & TTKSK & 141 & - & 52 & $3: 1$ & 0.39 & 0.53 & Sr22 & - \\
\hline $\mathrm{C} 3$ & PI 272557 & PI 190945 & TTTTF & 140 & - & 43 & $3: 1$ & 0.22 & 0.64 & Sr22 & - \\
\hline $\mathrm{C} 3$ & PI 272557 & PI 190945 & QFCSC & 107 & - & 37 & $3: 1$ & 0.04 & 0.85 & Sr22 & - \\
\hline $\mathrm{C} 4$ & PI 428151-1 & PI 190945 & TTKSK & 62 & - & 0 & - & - & - & - & Sr22 \\
\hline $\mathrm{C} 4$ & PI 428151-1 & PI 190945 & TTTTF & 160 & - & 0 & - & - & - & - & Sr22 \\
\hline $\mathrm{C} 4$ & PI 428151-1 & PI 190945 & QFCSC & 207 & - & 0 & - & - & - & - & Sr22 \\
\hline $\mathrm{C} 5$ & CI 2433 & PI 428151-1 & TTKSK & 52 & - & 4 & $15: 1$ & 0.08 & 0.78 & $\operatorname{Sr} 21, \operatorname{Sr} 22$ & - \\
\hline $\mathrm{C} 5$ & CI 2433 & PI 428151-1 & TTTTF & 16 & - & 6 & $3: 1$ & 0.14 & 0.71 & Sr22 & - \\
\hline $\mathrm{C} 5$ & CI 2433 & PI 428151-1 & QFCSC & 62 & - & 28 & $3: 1$ & 1.79 & 0.18 & Sr22 & - \\
\hline C6 & CI 2433 & PI 190945 & TTKSK & 14 & - & 1 & $15: 1$ & $4.44 \mathrm{E}-3$ & 0.95 & $\operatorname{Sr} 21, \operatorname{Sr} 22$ & - \\
\hline C6 & CI 2433 & PI 190945 & TTTTF & 44 & - & 18 & $3: 1$ & 0.54 & 0.46 & Sr22 & - \\
\hline $\mathrm{C} 7$ & PI 272557 & PI 272560 & TTKSK & 68 & - & 20 & $3: 1$ & 0.24 & 0.62 & Sr35 & - \\
\hline $\mathrm{C} 7$ & PI 272557 & PI 272560 & TTTTF & 66 & - & 21 & $3: 1$ & 0.03 & 0.85 & Sr35 & - \\
\hline $\mathrm{C} 8$ & PI 428151-1 & PI 272560 & TTKSK & 39 & 13 & 3 & $12: 3: 1$ & 0.88 & 0.64 & Sr22,Sr35 & - \\
\hline C9 & PI 272557 & PI $428170^{z}$ & TTKSK & 49 & - & 2 & $15: 1$ & 0.47 & 0.49 & $\operatorname{Sr} 21, \operatorname{Sr} 35$ & - \\
\hline $\mathrm{C} 10$ & PI 272557 & DV92 & TTKSK & 131 & 27 & 14 & $12: 3: 1$ & 1.87 & 0.39 & $\operatorname{Sr} 21, \operatorname{Sr} 35$ & - \\
\hline $\mathrm{C} 10$ & PI 272557 & DV92 & TTTTF & 110 & - & 31 & $3: 1$ & 0.68 & 0.41 & Sr35 & - \\
\hline $\mathrm{C} 10$ & PI 272557 & DV92 & MCCFC & 93 & - & 31 & $3: 1$ & 0 & 1 & $\operatorname{Sr} 21$ & - \\
\hline $\mathrm{C} 11$ & CI 2433 & DV92 & TTKSK & 63 & 15 & 0 & $3: 1$ & 1.38 & 0.24 & Sr35 & $\operatorname{Sr} 21$ \\
\hline $\mathrm{C} 11$ & CI 2433 & DV92 & TTTTF & 57 & - & 15 & $3: 1$ & 0.67 & 0.41 & Sr35 & - \\
\hline C11 & CI 2433 & DV92 & MCCFC & 78 & - & 0 & - & - & - & - & $\operatorname{Sr} 21$ \\
\hline $\mathrm{C} 12$ & PI 428170 & DV92 & TTKSK & 67 & - & 0 & - & - & - & - & Sr35, Sr 21 \\
\hline $\mathrm{C} 12$ & PI 428170 & DV92 & TTTTF & 75 & - & 0 & - & - & - & - & Sr35 \\
\hline $\mathrm{C} 12$ & PI 428170 & DV92 & MCCFC & 70 & - & 0 & - & - & - & - & $\operatorname{Sr} 21$ \\
\hline
\end{tabular}

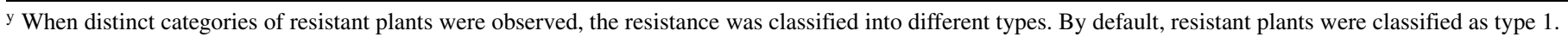
z Synonymous with G2919. 
Cereal Disease Laboratory, USDA Agricultural Research Service (ARS), S.t Paul, MN during December 2009 through February 2010. The greenhouse did not contain rusted plants in order to avoid contamination of spores. After full emergence of the primary leaf, $\approx 9$ days after planting, seedlings were inoculated.

Inoculum and inoculation. Inoculation of $P$. graminis $\mathrm{f}$. $\mathrm{sp}$. tritici isolates was performed in an inoculation booth at the Cereal Disease Laboratory during December 2009 through February 2010. The inoculation booth was washed with water between inoculations of plants with different $P$. graminis f. sp. tritici isolates in order to prevent contamination. P. graminis f. sp. tritici urediniospores were retrieved from storage at $-80^{\circ} \mathrm{C}$ and heat shocked at $45^{\circ} \mathrm{C}$ for $15 \mathrm{~min}$. Spores were rehydrated by placing the capsules in an air-tight container at $80 \%$ humidity maintained by a KOH solution for 2 to $4 \mathrm{~h}$ (17). Urediniospores were then suspended in a light-weight mineral oil (Soltrol 70; ConocoPhillips Inc., Houston) and sprayed onto seedlings. Plants were placed in dew chambers overnight as described previously (4).

Disease assessment and data analysis. After dew chamber incubation, plants were kept in a greenhouse in the Cereal Disease Laboratory maintained at $18 \pm 2^{\circ} \mathrm{C}$ for 14 days. ITs were classified on a 0-to- 4 scale 14 days after inoculation as described by Stakman et al. (19) (Fig. 1). The biological repeatability of visually scoring ITs on T. monococcum leaves has been reported previously in our lab to be $>95 \%$ (16). All visual scoring was performed by the same individual. ITs ' 0 ' to ' 2 ' and ' $\mathrm{X}$ ' or ' $\mathrm{Z}$ ' were classified as low ITs, indicating resistance; and ITs ' 3 ' and '4' were classified as high ITs, indicating susceptibility. In some populations, it was possible to discriminate among low IT classes. For each $\mathrm{F}_{2}$ population, the number of susceptible and resistant progenies (and sometimes various classifications of resistant progeny) were recorded. For the $\mathrm{F}_{2: 3}$ population, 15 to 20 seedlings were scored for each family and two replications were performed for each race screened. Based upon the combined data from two replications, families were classified as homozygous resistant, segregating, or homozygous susceptible to each race. In each population, the number of segregating resistance genes was predicted by comparing observed segregation ratios to expected ratios. Probabilities were determined using $\chi^{2}$ goodnessof-fit tests with $\alpha=0.05$ (performed with Microsoft Excel). Observed ratios significantly deviated from expected ratios when $P<0.05$.

\section{RESULTS AND DISCUSSION}

The presence of $S r 21, S r 22$, and $S r 35$ in the parental accessions. Postulated genes (Sr21, Sr22, or Sr35) segregated in several populations (Table 3). CI 2433 was demonstrated to possess $\mathrm{Sr} 21$ by The (21). Results of $\mathrm{F}_{2}$ progeny evaluation of the cross between CI 2433 and susceptible PI 272557 (C1) indicated the presence of a single dominant gene that provided resistance to race TTKSK (Table 3). Based on a previous study (16), Sr2l was determined to confer resistance to race TTKSK in the diploid background.

Accession RL 5244, previously demonstrated to possess Sr22 (7), was not available to us. However, both PI 190945 and PI 428151-1 (a single plant selection of PI 428151) have IT patterns identical to known lines with $\operatorname{Sr} 22(7,21)$. Segregation of resistance in populations derived from crosses between these two accessions and susceptible PI 272557 to races TTKSK, TTTTF, and QFCSC (crosses C2 and C3) indicated the presence of a single dominant gene (Table 3 ). When the accessions were crossed with each other (cross C4), all progeny were resistant (Table 3), indicating that the accessions have the same gene. Two genes segregated for resistance to race TTKSK in progeny of crosses of CI 2433 (Sr21) with PI 428151-1 (C5) and PI 190945 (C6). When tested with races QFCSC and TTTTF (both virulent on Sr21), segregation of resistance in the $F_{2}$ populations did not deviate significantly from $3: 1$, indicating a single dominant gene. These data indicate that resistance to races QFCSC and TTTTF in PI 190945 and PI 428151-1 is different from Sr21. Similarly, two genes segregated for resistance in the cross (C8) between PI 428151-1 and PI 272560 (postulated to possess Sr35), indicating that the resistance in PI 428151-1 is independent of Sr35. None of

TABLE 4. Segregation of resistance in Triticum monococcum $\mathrm{F}_{2}$ progeny derived from crosses with PI 277131-2 to races of Puccinia graminis f. sp. tritici

\begin{tabular}{|c|c|c|c|c|c|c|c|c|c|c|c|}
\hline Cross & Parent 1 & Parent 2 & Race & $\begin{array}{l}\text { Resistant } \\
\text { type } 1^{\mathrm{z}}\end{array}$ & $\begin{array}{c}\text { Resistant } \\
\text { type } 2\end{array}$ & $\begin{array}{l}\text { Resistant } \\
\text { type } 3\end{array}$ & Susceptible & $\begin{array}{l}\text { Expected } \\
\text { ratio }\end{array}$ & $\chi^{2}$ & $P$ & $\begin{array}{c}\text { Segregating } \\
\text { genes }\end{array}$ \\
\hline $\mathrm{C} 13$ & PI 272557 & PI 277131-2 & TTKSK & 102 & 25 & - & 14 & $12: 3: 1$ & 3.26 & 0.2 & 2 genes \\
\hline $\mathrm{C} 14$ & CI 2433 & PI 277131-2 & TTKSK & 280 & - & - & 0 & - & - & - & - \\
\hline $\mathrm{C} 14$ & CI 2433 & PI 277131-2 & TTTTF & 0 & - & - & 89 & - & - & - & - \\
\hline $\mathrm{C} 14$ & CI 2433 & PI 277131-2 & QFCSC & 106 & - & - & 40 & $3: 1$ & 0.45 & 0.5 & 1 gene \\
\hline $\mathrm{C} 14$ & CI 2433 & PI 277131-2 & MCCFC & 213 & - & - & 0 & - & - & - & - \\
\hline $\mathrm{C} 15$ & PI 190945 & PI 277131-2 & TTKSK & 206 & - & - & 0 & - & - & - & - \\
\hline $\mathrm{C} 16$ & PI 428170 & PI 277131-2 & TTKSK & 89 & 16 & 7 & 0 & $12: 3: 1$ & 1.49 & 0.48 & Sr35, 1 gene \\
\hline $\mathrm{C} 17$ & DV92 & PI 277131-2 & TTKSK & 80 & 27 & 5 & 0 & $12: 3: 1$ & 2.48 & 0.29 & Sr35, 1 gene \\
\hline
\end{tabular}

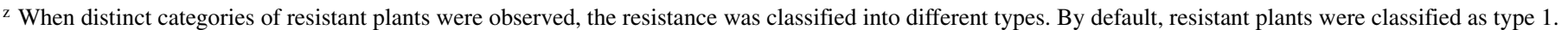

TABLE 5. Segregation of resistance in Triticum monococcum progeny derived from crosses with PI 306540 to races of Puccinia graminis f. sp. tritici

\begin{tabular}{|c|c|c|c|c|c|c|c|c|c|c|c|}
\hline Cross & Parent 1 & Parent 2 & Race & Gen. $^{x}$ & $\begin{array}{c}\text { Resistant } \\
\text { type } 1^{\mathrm{y}}\end{array}$ & Seg. $\left(F_{3}\right) / R 2\left(F_{2}\right)^{z}$ & Susceptible & $\begin{array}{l}\text { Expected } \\
\text { ratio }\end{array}$ & $\chi^{2}$ & $P$ & $\begin{array}{c}\text { Segregating } \\
\text { genes }\end{array}$ \\
\hline C18 & PI 272557 & PI 306540 & TTKSK & $\mathrm{F}_{3}$ & 42 & 28 & 0 & $37: 26: 1$ & 1.16 & 0.56 & 3 genes \\
\hline $\mathrm{C} 18$ & PI 272557 & PI 306540 & TTTTF & $\mathrm{F}_{3}$ & 12 & 40 & 18 & $1: 2: 1$ & 2.46 & 0.29 & 1 gene \\
\hline $\mathrm{C} 18$ & PI 272557 & PI 306540 & QFCSC & $\mathrm{F}_{3}$ & 29 & 38 & 5 & $7: 8: 1$ & 0.37 & 0.83 & 2 genes \\
\hline C19 & CI 2433 & PI 306540 & TTKSK & $\mathrm{F}_{2}$ & 395 & - & 0 & - & - & - & - \\
\hline $\mathrm{C} 19$ & CI 2433 & PI 306540 & TTTTF & $\mathrm{F}_{2}$ & 80 & - & 25 & $3: 1$ & 0.08 & 0.78 & 1 gene \\
\hline C19 & CI 2433 & PI 306540 & QFCSC & $\mathrm{F}_{2}$ & 142 & - & 9 & $15: 1$ & 0.02 & 0.88 & 2 genes \\
\hline $\mathrm{C} 20$ & PI 428151-1 & PI 306540 & TTKSK & $\mathrm{F}_{2}$ & 453 & - & 0 & - & - & - & - \\
\hline $\mathrm{C} 20$ & PI 428151-1 & PI 306540 & TTTTF & $\mathrm{F}_{2}$ & 63 & 15 & 4 & $12: 3: 1$ & 0.30 & 0.86 & $S r 22,1$ gene \\
\hline $\mathrm{C} 20$ & PI 428151-1 & PI 306540 & QFCSC & $\mathrm{F}_{2}$ & 183 & - & 5 & $63: 1$ & 1.47 & 0.23 & $S r 22,2$ genes \\
\hline $\mathrm{C} 21$ & DV92 & PI 306540 & TTKSK & $\mathrm{F}_{2}$ & 181 & 59 & 0 & $3: 1$ & 0.02 & 0.88 & Sr35 \\
\hline
\end{tabular}

${ }^{\mathrm{x}}$ Generation.

${ }^{y}$ When distinct categories of resistant plants were observed, the resistance was classified into different types. By default, resistant plants were classified as type 1 .

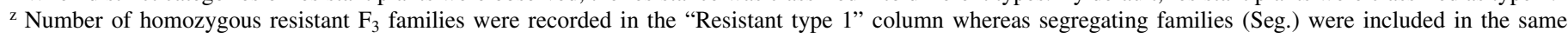
column as Resistant type 2 (R2). 
the evidence available to us indicates that the single gene in PI 190945 and PI 428151-1 is not $\mathrm{Sr} 22$.

The source of Sr35, PI 428170 (G2919), was demonstrated to also possess $\mathrm{Sr} 21$ by McIntosh et al. (9). Because the majority of T. monococcum accessions possess $\operatorname{Sr} 21(16,21)$, it is not surprising that an accession with $\mathrm{Sr} 35$ also carries $\mathrm{Sr} 21$. Accession PI 272560 appeared to possess Sr35 and not Sr21 (Table 3). Unfortunately, crosses to PI 272560 were rarely successful. However, we did establish that resistance in PI 272560 to races TTKSK and TTTTF is inherited as a single dominant gene (C7) (Table 3), confirming that $\mathrm{Sr} 35$ is present alone in this line. Two genes segregated for resistance in PI 428170 to race TTKSK (Sr21 and Sr35; C9) (Table 3). Accession DV92 showed ITs and race specificity identical to PI 428170, indicating that DV92 also possessed Sr21 and Sr35 (22). Results from examining segregation of progeny between DV92 and susceptible PI 272557 (C10) indicated the presence of two genes that confer resistance to race TTKSK (Sr21 and Sr35), one to race TTTTF (Sr35), and one to race MCCFC $(\mathrm{Sr} 21)$. The presence of $S r 21$ in DV92 was also confirmed by examining segregation of resistance in the cross between DV92 and CI 2433 (C11). Susceptible progeny were not observed in the cross between PI 428170 and DV92 (C12) when tested with the three races, indicating that the accessions possess the same genes.

In all population-race combinations, the number of segregating genes matched our expectations based upon gene postulations

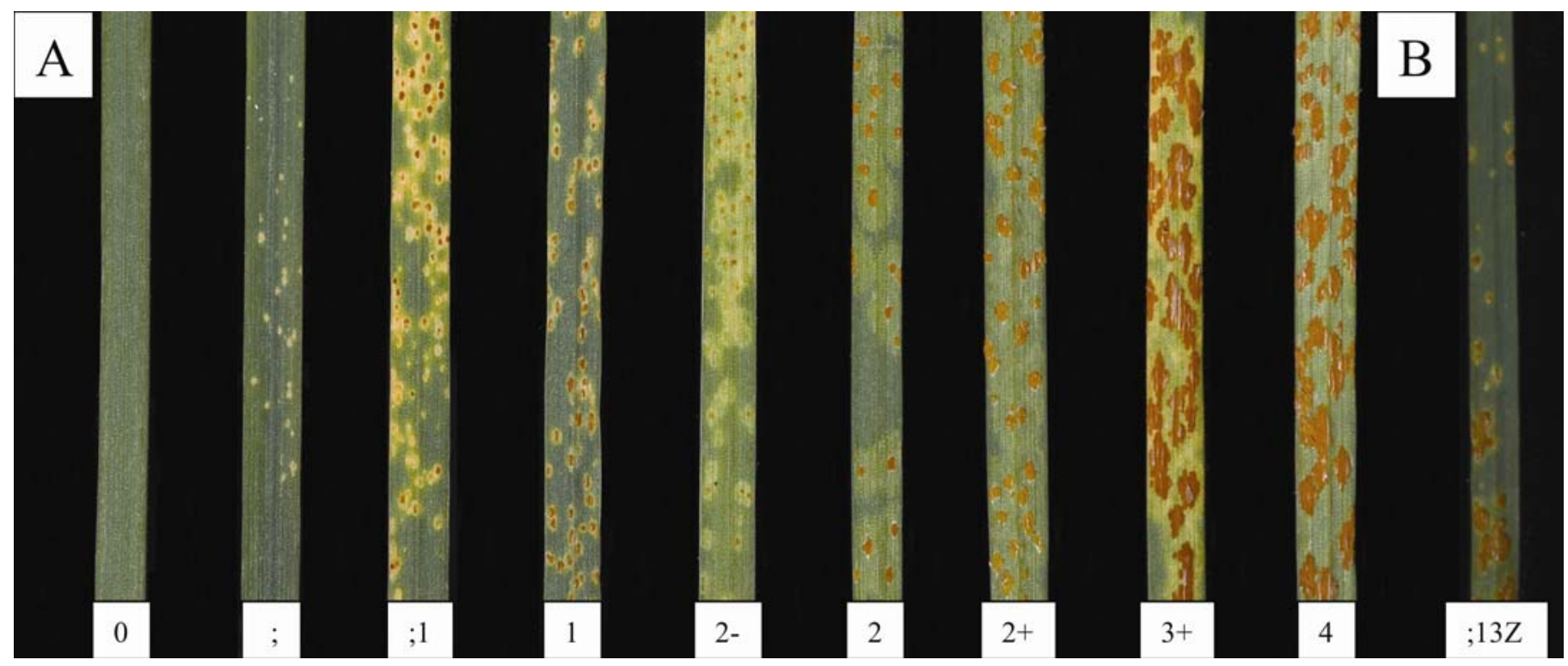

Fig. 1. A, Infection types produced on seedling leaves of Triticum monococcum by inoculating with races of Puccinia graminis f. sp. tritici; B, mesothetic infection type.
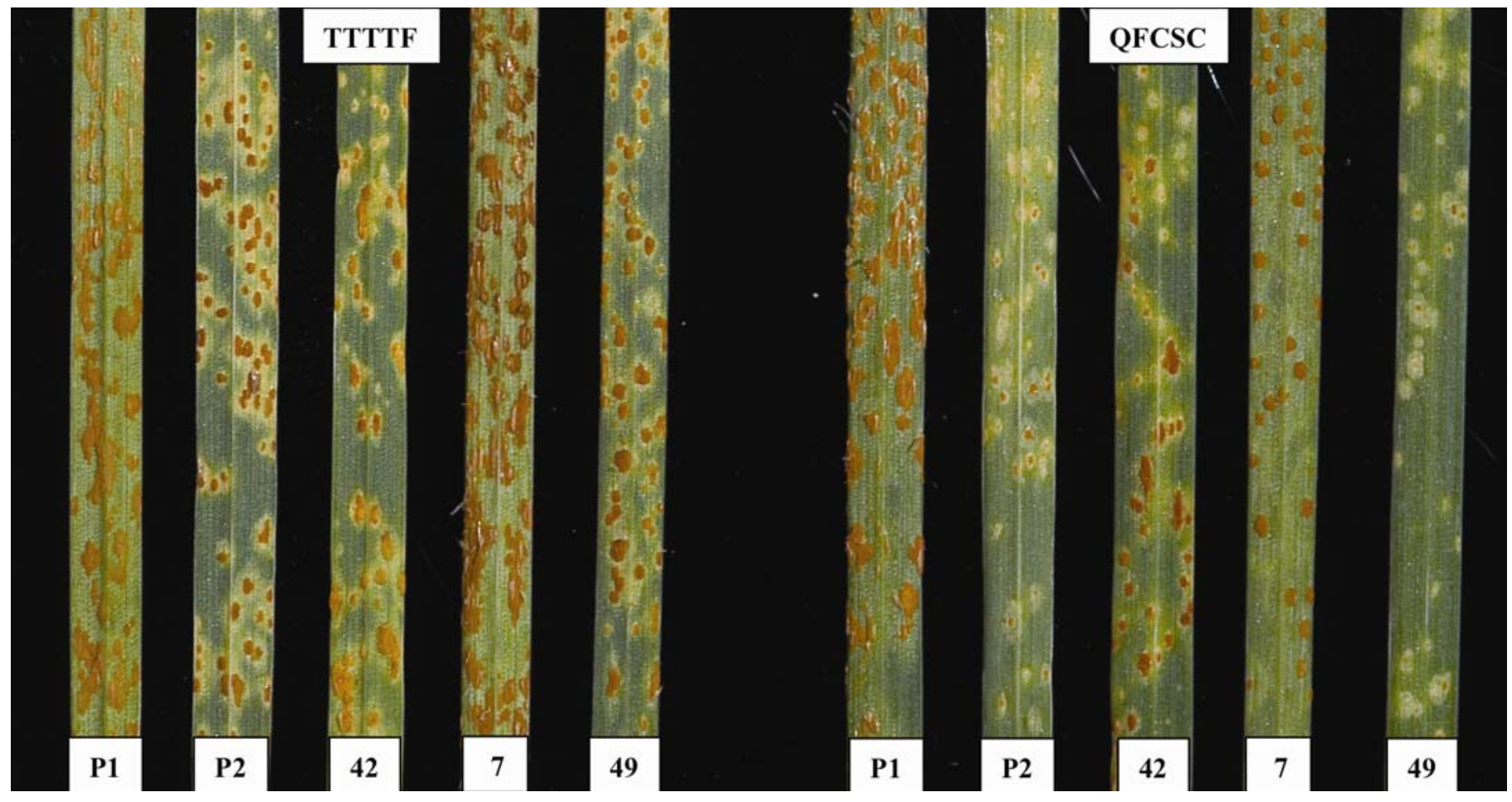

Fig. 2. Infection types produced on selected PI 272557/PI $306540 \mathrm{~F}_{3}$ families homozygous for response and parents $(\mathrm{P} 1=\mathrm{PI} 272557$ and P2 $=$ PI 306540$)$ inoculated with races TTTTF and QFCSC of Puccinia graminis f. sp. tritici. 
(16). Additionally, our results validated the gene postulations and genetics in previous studies of accessions Einkorn, G2919 (PI 428170), and DV92 (9,21,22). Genes $S r 21, S r 22$, and Sr35 segregated independently as expected because they are located on different chromosomes (2AL, 7AL, and 3AL, respectively) (7,9, $12,21,22)$. The confirmation of presence of $\operatorname{Sr} 21, \operatorname{Sr} 22$, and $S r 35$ through these genetic analyses is an essential prerequisite for examining the genetics of resistance in accessions postulated to possess new resistance genes.

Resistance in PI 277131-2. Accession PI 277131-2 is a single plant selection from PI 277131 that we postulated to possess new resistance to race TTKSK. The IT pattern exhibited by PI 2771312 cannot be explained by the presence of $S r 21, S r 22$, or $S r 35$ alone or in combination (Table 1). The high IT of PI 277131-2 to race TTTTF indicates that PI 277131-2 does not possess Sr35. The high ITs to races TTTTF and TRTTF indicate that PI 2771312 does not possess $S r 22$. The IT pattern does not provide enough information to determine whether or not PI 277131-2 possesses Sr21. However, the low IT to race QFCSC indicates that, if Sr21 is present in PI 277131-2, then additional genes are present conferring resistance to this race. Two genes resistant to race TTKSK segregated in the $F_{2}$ progeny of the cross between PI 277131-2 and susceptible PI 272557 (C13) (Table 4).

In order to determine whether one of the genes in PI 277131-2 is $\operatorname{Sr} 21, \mathrm{~F}_{2}$ progeny from a cross to CI $2433(\mathrm{Sr} 21$; C14) were examined. One gene segregated for resistance to race QFCSC (virulent on $\mathrm{Sr} 21$ ) and susceptible progeny were not observed when race MCCFC (avirulent on $\mathrm{Sr} 21$ ) was used in the progeny evaluation. These data suggest that one of the genes for resistance to race TTKSK in PI 277131-2 is Sr21 and that the other gene is likely new because it is susceptible to race TTTTF; thus, the possibilities of either $\mathrm{Sr} 22$ or $\mathrm{Sr} 35$ were excluded. To determine the allelic relationship between the new gene and $\mathrm{Sr} 22$ and $\mathrm{Sr} 35$, crosses were made to PI 190945 (Sr22; C15), PI 428170 (Sr21 and $\mathrm{Sr} 35$; C16), and DV92 (Sr21 and Sr35; C17). No $\mathrm{F}_{2}$ progeny were found to be susceptible from the cross with PI 190945 (Sr22; C15). This result is likely due to the small population size sampled or a gene allelic or linked to Sr22. Segregation of resistance to race TTKSK between PI 277131-2 and both DV92 and PI 428170 (C16 and C17) indicated the presence of three distinct classes of resistant phenotypes that did not deviate significantly from a 12:3:1 ratio. This is consistent with the expectation that $S r 21$ was fixed in these populations with $\operatorname{Sr} 35$ and the new gene segregating. These data indicate that the new gene is independent of Sr35. The '0' to '0;' low IT to race TTKSK on Sr35 facilitated identification of lines without Sr35 but still resistant (with $\mathrm{Sr} 21$ and, sometimes, the new gene).

Resistance in PI 306540. Accession PI 306540 was postulated to possess new resistance to race TTKSK because of its unique IT pattern to the races screened (Table 1). PI 306540 is resistant to all races screened but the mesothetic reactions observed with race TRTTF were not consistent with ITs produced by accessions with Sr22 or $\operatorname{Sr} 35(7,22)$ (Table 1). Analysis of $F_{2: 3}$ progeny derived from the cross between PI 306540 and susceptible PI 272557 (C18) indicated segregation for three genes resistant to race TTKSK, two genes resistant to race QFCSC, and one gene resistant to race TTTTF (Table 5). Selected plants from homozygous families of this population and the parents inoculated with races TTTTF and QFCSC are displayed in Figure 2. Family 42 possesses resistance that mediates a complex IT $(; 13 \mathrm{Z})$ to races TTTTF and QFCSC (the middle of the leaves are displayed in Figure 2). Family 7 possesses resistance that mediates a ' 2 ' IT to race QFCSC but is susceptible to race TTTTF. Family 49 possesses both types of resistance, resulting in the parental IT to both races TTTTF and QFCSC.

Crossing of PI 306540 with CI 2433 (Sr21; C19) indicated that one of the genes mediating resistance to race TTKSK in PI 306540 could have been $S r 21$ (Table 5). However, the limited population size is not sufficient to derive a firm conclusion. The resistance genes present in PI 306540 to races QFCSC and TTTTF are independent of $S r 21$ because these races are virulent on $\operatorname{Sr} 21$. The presence of only two genes resistant to race QFCSC in PI 306540 and one gene resistant to race TTTTF is consistent with the hypothesis that one of the three genes resistant to race TTKSK in PI 306540 is Sr21 because races QFCSC and TTTTF are virulent on $\mathrm{Sr} 21$. Results from examining progeny of the cross between PI 428151-1 (Sr22) and PI 306540 (C20) indicated that resistance to races TTTTF and QFCSC in PI 306540 is independent of Sr22. The sample size of plants observed was not sufficient to test whether or not resistance to race TTKSK is conferred by loci independent of $S r 22$. Progeny of the cross between PI 306540 and DV92 (Sr21 and Sr35; C21) segregated for the '0' to '0;' low IT, indicative of $\mathrm{Sr} 35$, demonstrating the independence of resistance in PI 306540 to race TTKSK from Sr35.

In summary, of the three genes resistant to race TTKSK in PI 306540, (i) one may be $S r 21$, (ii) a new gene is present that confers a ';13Z' IT, and (iii) a second new gene is present that confers a ' 2 ' IT. The gene exhibiting IT ';13Z' appears to confer resistance to all races screened. Based upon race-specificity and IT, the second new gene with the ' 2 ' IT could be the same as the new gene identified in PI 277131-2. Crossing PI 277131-2 with PI 306540 and evaluating a large number of progeny with race QFCSC may determine whether resistance in the two accessions is independent.

Overall, we described at least two new stem rust resistance genes present in the $T$. monococcum germplasm investigated. We have initiated experiments to map the new resistance genes to facilitate the introgression of small segments of $T$. monococcum possessing resistance to race TTKSK into wheat. Studies are needed to evaluate the effect of the newly described resistance genes in a hexaploid background at both seedling and adult plant stages. This study contributed to the "toolbox" of resistance genes available to breeders for pyramiding multiple resistance genes into elite breeding lines in order to obtain durable resistance to stem rust.

\section{ACKNOWLEDGMENTS}

Funding for this research was provided by the USDA-ARS and the Durable Rust Resistance in Wheat project funded by the Bill and Melinda Gates Foundation. This research would not be possible without technical support from L. Wanschura, S. Gale, P. Olivera, and several University of Minnesota undergraduate student technicians. We thank two anonymous reviewers for helpful changes to the text.

\section{LITERATURE CITED}

1. Fetch, T., Jr. 2007. Virulence of stem rust race TTKS on Canadian wheat cultivars. Can. J. Plant Pathol. 29:441.

2. Gerechter-Amitai, Z. K., Wahl, I., Vardi, A., and Zohary, D. 1971. Transfer of stem rust seedling resistance from wild diploid einkorn to tetraploid durum wheat by means of a triploid hybrid bridge. Euphytica 20:281-285.

3. Jin., Y., and Singh, R. P. 2006. Resistance in U.S. wheat to recent Eastern African isolates of Puccinia graminis f. sp. tritici with virulence to resistance gene Sr31. Plant Dis. 90:476-480.

4. Jin, Y., Singh, R. P., Ward, R. W., Wanyera, R., Kinyua, M., Njau, P., Fetch, T., Pretorius, Z. A., and Yahyaoui, A. 2007. Characterization of seedling infection types and adult plant infection responses of monogenic $\mathrm{Sr}$ gene lines to race TTKS of Puccinia graminis f. sp. tritici. Plant Dis. 91:1096-1099

5. Jin, Y., Szabo, L. J., Pretorius, Z. A., Singh, R. P., Ward, R. W., and Fetch, T., Jr. 2008. Detection of virulence to resistance gene $S r 24$ within race TTKS of Puccinia graminis f. sp. tritici. Plant Dis. 92:923-926.

6. Jin, Y., Szabo, L. J., Rouse, M. N., Fetch, T., Jr., Pretorius, Z. A., Wanyera, R., and Njau, P. 2009. Detection of virulence to resistance gene Sr36 within the TTKS race lineage of Puccinia graminis f. sp. tritici. Plant Dis. 93:367-370.

7. Kerber, E. R., and Dyck, P. L. 1973. Inheritance of stem rust resistance transferred from diploid wheat (Triticum monococcum) to tetraploid and hexaploid wheat and chromosome location of the gene involved. Can. J. 
Genet. Cytol. 15:397-409.

8. Leonard, K. J. 2001. Stem rust-future enemy? Pages 119-146 in: Stem Rust of Wheat: From Ancient Enemy to Modern Foe. P. D. Peterson, ed. American Phytopathological Society Press, St. Paul, MN.

9. McIntosh, R. A., Dyck, P. L., The, T. T., Cusick, J., and Milne, D. L. 1984. Cytogenetical studies in wheat XIII. Sr35-a third gene from Triticum monococcum for resistance to Puccinia graminis tritici. Z. Pflanzenzucht. 92:1-14.

10. Nazari, K., Mafi, M., Yahyaoui, A., Singh, R. P., and Park, R. F. 2009. Detection of wheat stem rust (Puccinia graminis f. $\mathrm{sp}$. tritici) race TTKSK (Ug99) in Iran. Plant Dis. 93:317.

11. Niu, Z., Klindworth, D. L., Friesen, T. L., Chao, S., Jin, Y., Cai, X., and $\mathrm{Xu}, \mathrm{S}$. S. 2011. Targeted introgression of a wheat stem rust resistance gene by DNA marker-assisted chromosome engineering. Genetics 187:1011-1021.

12. Olson, E., Brown-Geudira, G., Marshall, D., Stack, E., Bowden, R. L., Jin, Y., Rouse, M., and Pumphrey, M. O. 2010. Development of wheat lines having a small introgressed segment carrying stem rust resistance gene Sr22. Crop Sci. 50:1823-1830.

13. Olson, E. L., Brown-Guedira, G., Marshall, D. S., Jin, Y., Mergoum, M., Lowe, I., and Dubcovsky, J. 2010. Genotyping of U.S. wheat germplasm for presence of stem rust resistance genes $\operatorname{Sr} 24, \operatorname{Sr} 36$, and $\operatorname{Sr} 1 R S^{\text {Amigo }}$. Crop Sci. 50:668-675.

14. Pretorius, Z. A., Bender, C. M., Visser, B., and Terefe, T. 2010. First report of a Puccinia graminis f. sp. tritici race virulent to the Sr24 and
Sr31 wheat stem rust resistance genes in South Africa. Plant Dis. 94:784.

15. Pretorius, Z. A., Singh, R. P., Wagoire, W. W., and Payne, T. S. 2000. Detection of virulence to wheat stem rust resistance gene $\mathrm{Sr} 31$ in Puccinia graminis f. sp. tritici in Uganda. Plant Dis. 84:203.

16. Rouse, M. N., and Jin, Y. 2011. Stem rust resistance in A-genome diploid relatives of wheat. Plant Dis. 95:941-944.

17. Rowell, J. B. 1984. Controlled infection by Puccinia graminis f. sp. tritici under artificial conditions. Pages 292-332 in: The Cereal Rusts, Vol. 1. Origins, Specificity, Structure, and Physiology. W. R. Bushnell and A. P. Roelfs, eds. Academic Press, Orlando, FL.

18. Singh, R. P., Hodson, D. P., Huerta-Espino, J., Jin, Y., Njau, P., Wanyera, R., Herrera-Foessel, S. A., and Ward, R. 2008. Will stem rust destroy the world's wheat crop? Adv. Agron. 98:271-309.

19. Stakman, E. C., Stewart, D. M., and Loegering, W. Q. 1962. Identification of physiologic races of Puccinia graminis var. tritici. United States Department of Agriculture-Agricultural Research Service E-617.

20. The, T. T. 1973. Chromosome location of genes conditioning stem rust resistance transferred from diploid to hexaploid wheat. Nat. New Biol. 241:256.

21. The, T. T. 1973. Transference of resistance to stem rust from Triticum monococcum L. to hexaploid wheat. Ph.D. thesis, The University of Sydney.

22. Zhang, W., Olson, E., Saintenac, C., Rouse, M., Abate, Z., Jin, Y., Akhunov, E., Pumphrey, M., and Dubcovsky, J. 2010. Genetic maps of stem rust resistance gene $\mathrm{Sr} 35$ in diploid and hexaploid wheat. Crop Sci. $50: 2464-2474$ 